\title{
The Rise of British Cultural Identity in Othello by Shakespeare
}

\author{
Dramane Ouattara, Doctoral Student \\ Department of English, Alassane Ouattara University of Bouake, \\ Cote d'Ivoire
}

Doi:10.19044/esj.2020.v16n29p177 URL:http://dx.doi.org/10.19044/esj.2020.v16n29p177

\begin{abstract}
The rise of British cultural identity in Othello by Shakespeare stands as a special message to the non-native. It was a patriotic address Shakespeare intended for people who were not British and inhabited England of Queen Elizabeth the $1^{\text {st }}$. The paper analyses the foul and rude treatment of Elizabethan ways on the part of the people Shakespeare and the British community willingly accepted, then integrated into their society as an ordinal citizen. At the top of outraged British people, the preoccupation of Shakespeare with the issue of the rise of British cultural identity was illustrative than ever in his play. His hope and craving for a multi-cultural British society culminated in the societal project. The project was meant to campaign for the rise and promotion of a cultural identity typical of British ways and customs. In a word, the implementation of the societal project of the playwright would certainly allow British cultural identity to go up in value within the ongoing globalised world inclined to cultural homogenization of identities.
\end{abstract}

Keywords: British, culture, identity, non-native, integration

\section{Introduction}

The issue of the rise of British cultural identity in Othello by Shakespeare must be set in the context of the identity crisis that originated from the confrontation of British cultural identity with foreign ones. In this study, the understanding of the term cultural identity is accessed through the prism of Moha Ennaji's definition of this notion. To Ennaji, cultural identity "refers to the way people see or define themselves, and how their identity relates to the world" (2005, p.19-23). Cultural identity stands therefore as shared characteristics exclusive to people of the given country. With regard to the special social traits and ways that found a nation, or some people, a British did not share common practices with an African, and an African behaved in accordance with the ways specific to his cultural identity. 
In England, Shakespeare and British people were favourable to the integration of non-British people into their society. In that perspective, the settlement of aliens in England dated from the early fifteenth century. Like Othello the Moor in Venice, a non-native was already set up at the Court of Henry VI as a musician. By keeping his identity of Moor, Othello was socially integrated into the Venetian community and held the position of the General of Army. Similarly, John Blanke (1507-1512) or "the royal Black Trumpeter" used to perform at the Court of British sovereigns for monthly payment.

Upon the ascension of Queen Elizabeth the $1^{\text {st }}$ on British Crown in 1558, the country experienced social tranquillity and envious economic growth. Owing to the improved social and economic environment, England was invaded by non-native people all over the world. The Queen was not also firmly opposed to the establishment of foreign people. In fact, Elizabeth was rather favourable to international collaboration, and she was actively determined to set up strong and constant exchange with the outside world. Through this means, the free settlement and social integration of many nonBritish people in England during her ruling, was a telling expression of the generosity and flexibility of the Queen's foreign policy. The British and Foreign Review (1838) underpinned the vision at the heart of the international policy of the Queen. The work further explained that the Queen admitted that "By giving [alien] man a resource against starvation, we withdraw from him his greatest motive from entering into an engagement to pay a rent which [may] leave him the poorest [again]" (352). Due to the British foreign policy of toleration, whereby the country genuinely provided strangers with adequate assistance and accommodation, Shakespearean Elizabethan England became a welcome opportunity for the influx of immigrants in early $16^{\text {th }}$ century.

With the flexibility of the Venetian foreign policy, Othello got married to a Venetian lady and hoped to spread out his Moorish identity by the coming babies with his Venetian wife. At the same time, the humanly-slanted foreign policy of the Queen contributed to the growth of the number of non-native people. Likewise, the influence Shakespearean Othello exerted on Venetian politics and tradition equated with the striking impact non-British people maintained on British affairs. Regarding the brutal shift of this paradigm, Shakespeare condemned the fact that Desdemona, a virgin Venetian lady, got married outside the traditional environment of Venice. Also, Michelle M. Dowd and Natasha Korda drew British minds on the growing influence which British aliens held genuinely on the Elizabethan finance. In their seminal work Working Subjects in Early Modern England Drama (2011), the scholars observed that:

The cultural impact of the massive numbers of Dutch - and French-speaking Protestant [...] who migrated to England [...] is well known that many of these religious refugees were 
skilled artisans in the luxury textile and clothing trades and that their importation of new skills and technologies of manufacture had a huge impact on this sector of the economy" (9).

The underlying insights of the revelation of the scholars operated as an ear-splitting voice that echoed in British subconscious, refreshing their minds on coming threatening issues. Thus, the spread of this threat would certainly jeopardize their cultural identity. British finance was partly on the grip of aliens. In $O T H$, their cultural identity was on the threshold of the total explosion. On the same ground, the denunciation process led by Shakespeare came up as an urgent invitation to think of the British traditional ways and customs in order to perpetuate the true cultural identity of British people.

This paper focuses on defending and promoting the cultural identity of British society that was faced with menaces of foreign identity. To put it differently, through its three-party steps and its sociocritical approach, the kernel of the paper as far as the British identity is concerned aims to pinpoint Shakespeare craving and to condition the playwright established to heighten a true British cultural identity at the moment this identity was overshadowed by the growing impact of foreign cultural identity. Shakespeare epitomized the prominence of non-British cultural identity through the growing notoriety of what John Drakakis termed "the forces of otherness' [s]" (2008, p.185) ways over Venetian ${ }^{1}$ ones.

\section{Senator Brabantio: The Defender and Promoter of Venetians' Cultural Identity}

Defending and protecting the Venetian cultural identity was the societal strategy at the heart of the policy Shakespeare applied in OTH. To implement this strategy, the playwright employed Venetians, and Senator Brabantio was at the forefront of the scheme. He was the father to Desdemona, the most virtuous and beautiful lady of Venice. The father to Desdemona expressed strong love for Venetian traditions and ways. In terms of obedience and respect for one's cultural identity, Brabantio was the opposed image of many Shakespearean characters, including King Lear. In the affair of the wedding between Othello and Desdemona, critics hurriedly depicted

\footnotetext{
${ }^{1}$ Venice, not London, is the City Shakespeare staged the plot of $O T H$. In fact, the Italian city operates as a metaphor to the play. Graham Holderness (2010) admits that "Shakespeare's Venice is a thinly disguised cover for Shakespeare's England" (1). Otherwise, the playwright had England in mind when he located his play in Italy. The argument I am about to raise and clarify is that Shakespeare's Venice, in term of practices, equates with Shakespearean Elizabethan London of the same epoch. It is proved that the playwright is rather led by the universal characteristics of European habits and customs that permeated not only in Venice and London, but also Denmark, France, Milan, and Naples which are interconnected culturally speaking.
} 
Brabantio as a racist or xenophobic figure. A category of critics, including Azmil M. Zabidi (1990), dared to underscore racism as the social ideology Brabantio practiced in the play. This reductive-oriented approach is detrimental to the amount of positive traditional values Shakespeare bestowed on the Senator.

Shakespeare placed the father to Desdemona at the pivotal standing of the safeguarding scheme of the cultural identity he initiated so far. Brabantio was the central figure in Shakespeare's patriotic fight against the intruder, namely those aliens who showed dispositions and energetic determinations to weaken and damage Venetian identity. With regard to the important social role bestowed on Brabantio, Martin Orkin justified the atypical fury of a traditional father when he asserted that "Brabantio's grief [has] come to an understanding of the fact of his daughter's disobedience" (1987, p.169). Disobedience was the key to the attitude of Desdemona. Neither Venice, Shakespeare, nor Brabantio could comprehend the new attitude Lady Desdemona adopted. In a bid to obtain persuasive explanations about the innovating behaviour of his daughter, the Senator enrolled the issue on the legendary stuff of national concern. At the Senate, the father to Desdemona exposed all the evil and the mischief his daughter's inopportune wedding with Othello caused to his mind and to the reputation of Venice. Brabantio started saying that "She has deceived her father, [this] particular grief/ Is of so flood-gate and o'erbearing nature/ That it engluts and swallows other sorrows". He continued, "in spite of nature. / Of years, of country, credit, everything - /To fall in love with what she fear'd to look on/ And it is still itself' $(O T H, 1.3 .48)$. Senator Brabantio further mentioned the devastating and unvenetian daughterhood attitude Othello made Desdemona undertake.

Shakespeare could notice that Desdemona left the house of her father, sometime against his consent, and other time trampling on the authority of Brabantio. Hence, this unpleasant situation was, to the mind of Brabantio, something innovative in his daughter's behaviour. This is because of the way a Venetian daughter was expected to behave regarding father-daughter relationship. Indeed, in the father-daughter relationship, any transgressive behaviour is severely punished by the Venetian patriarchal society. In that society, the father-daughter relationship was representative of the paradigm of the ruler and the ruled. Based on his exploration of this paradigm, Tallent Lenker asserted that "[in patriarchal society, the passiveness of daughters] was part of the normal order of family life which is inherently dynamic [because] daughters were acted upon [...]" (Lenker, 2001, p.63). So to speak, a patriarchal daughter was submissive to her father who "rules supreme" (2001, p.63). Lenker laid emphasis on the fact that, in a male-oriented society, a daughter was naturally aware of her indebtedness to parents and "the wishes of the father". Lenker also noticed "subsume of those of the daughter" (2001, 
p.49). Reasonably, the revelation of Desdemona's atypical marriage with Othello acted negatively upon Brabantio, her father. It flared up Brabantio’s feeling of tradition and fuelled his mind with anger and fury. Brabantio's craving for taking Desdemona from the wild and savage grip of Othello turned out into man-hunting $(O T H, 1.1)$. Stranger Othello became wanted in Venice. He was looked for in each nook of the town by armed soldiers. The sooner the Mauritanian Prince was found, the better for Venice because the Senator was ready to go through doors from top to bottom.

The activist of traditional values which the Senator dressed in was meant to restore order from the chaotic atmosphere that his daughter's wedding brought about in Venice. Brabantio intended to lead his Desdemona. The Senator wanted to take advantage of the marriage occasion to organise the wedding ceremony of his daughter the way it used to be in Venice. It seemed clear that the attachment of Brabantio to his cultural ways and his opposition to the way Othello imposed on his daughter to get married, transcended the simple question of Othello's race. It is rather "an ideological conception act of [father-daughter relationship]" which to the mind of Edmond Cros "should serve, precisely to reveal the nature and function [of that traditional bond] in our societies" (1988, p.3) and in Venice very specifically. The focal point of Brabantio's activisms which Cros observed remained the construction of the authentic social meaning via the strict submission of Desdemona to the principle that regulated father-daughter bond in Venice some years ago. Thus, following the path Cros explored, the brilliant exposition of Brabantio at the Senate laid bare his attachment to those fundamental laws. Also, Brabantio's continual reference to the respect of father's authority was fitted for the same perspective.

The strategy of Brabantio to re-deem the lost soul of his daughter consisted of exhibiting the idealistic and protective father that only the patriarchal system could afford. Daughters in the mind of Brabantio were brought up and cared for properly through the protective trend of the patriarchal system. Brabantio insisted on this point as it was the step which provided his daughter with the indispensable parental blessing and foundation for genuine social identity. Secondly, like Desdemona who led a solitary project taking decisions according to her exclusive viewpoint, Brabantio attempted to drive Desdemona from this dead end path. This is because the Senator knew that in the Venetian society, a daughter should walk in the paths which her father has instructed her to step in. Finally, Brabantio decided to oppose things Desdemona planned, did, and enterprised as far as her wedding was concerned. This undertaking aimed at correcting her evil or misbehaving manners. So to speak, the father to Desdemona got engaged in the process of correcting Desdemona's social behaviour by framing her enactment according to Venetian cultural identity. Ultimately, Shakespearean Brabantio made it 
clear that Desdemona ought to abandon any project of decision-making she already started. In marriage affairs, Brabantio believed that the wish of a Venetian's daughter remains passive until it is given an impetus by the active decision of her father, who is truly the decision-maker (Lenker, 2001).

Following the sensitizing policy Brabantio undertook, the father to Desdemona enlightened his daughter about a possible terrible outcome that may result from the path she engaged in. By choosing her man, and deciding to marry outside the cultural and familial environment, Brabantio thought his daughter committed the most dishonourable feat Venice never experienced. Brabantio warned that the stubbornness of Desdemona would cause her social and household troubles. The pretence of the loss of the wedding gift her Othello offered her worthily precipitated her going down into the underworld. Also, without established proof, the husband of Desdemona killed her on the basis of her supposed unfaithfulness $(O T H, 5.2)$. Desdemona still acted as an emancipated woman with her father and Othello, her spouse.

Based on his experiences of social matters, particularly on the scope of marriage affairs viewed on the prism of Venetian ways, Senator Brabantio was the skilfull personality to exhibit devastating end from the ill-shaped amorous relationship his daughter embarked on. Being a Venetian elder, Brabantio was quite aware of the way his traditional society operated. The father to Desdemona could also account for the cause of most of the Venetian household troubles, and Brabantio's unfortunate prediction proved to be effective in the play. Desdemona is assassinated by the man she preferred at the detriment of her father and cultural ways. Her incapacity to adapt to Othello's Mauritanian ways and her absolute rejection of her Venetian practices resulted in her premature destruction. Furthermore, from the restless mind of her father, one could understand that the untimely death of Desdemona had a close link with the way she perceived and accessed her traditional and cultural practices. It was believed that the daughter to Brabantio used to deny her identity by disregarding the Venetian custom. Therefore, it seemed quite true that Desdemona would have stayed alive if only she had a consideration for the way her father celebrated the wedding of the Venetian daughters.

\section{Celebrations: An Optimal Way to Perpetuate Venetians' Cultural Identity}

A traditional celebration constitutes a welcome opportunity to show and implement the way one's culture works. Such a traditional occasion stands as a powerful medium to communicate with one's people exhibiting some cultural aspects in regard to one's identity. Being the core aspect of the cultural event, traditional celebration is regarded as an excellent opportunity to stay connected with one's ways and roots. It is believed that, by attending a 
celebration, people discover and experience the way their cultural event is carried out by the community. In fact, traditional celebrations offer opportunities fostered by reinforcing the discovery of the cultural identity to people. In Shakespearean Elizabethan England, Jeffrey L. Singman accessed traditional celebrations as essential steps that release people from acculturation framing their daily actions. In Daily Life in Elizabethan England (1995), Singman explained that "Celebrations were firmly established in the popular mind [...] for whom such [events] gave shape to their lives" (60). In his work, Singman focused on the importance of celebration for British people the way Shakespearean Brabantio emphasised the necessity for his daughter to be wedded according to the cultural code that founded Venetian identity.

Shakespeare Brabantio hung on the occasion of his daughter's marriage to teach the tenets and exhibit the different aspects of Venetian cultural identity as far as wedding ceremony was concerned. Brabantio was convinced that teaching, showing, and explaining these cultural codes to Desdemona may help her smoothly achieve some essential aspects of Venetians' culture. First, Brabantio debated the question related to the choice of one's mate or would-be husband. In Shakespearean Venetian Renaissance epoch, the choice of a husband or bride was parents' matter. Also, at that time, marriage was a means to transfer family wealth or some of its goods to the bridegroom. Marriage as Stone put it later "was for centuries one of the most common mechanisms for the transfer and redistribution of property" (Stone, 1977, p.22). The process of wealth transfer, according to Stone and Renaissance people, gave rise to what is referred to as arranged marriages. In fact, at the Renaissance time, a pre-conceived ideology seemed to exist on marriage. Marriage was an arrangement and occurred between families holding the same social status. It was in one of those families that parents, in most cases, particularly the father decided who his son or daughter would get married to.

Arranged marriage was a key element in Shakespearean Venetian way of organizing wedding ceremonies. It occurred between families of the same social rank. Stone led a seminal investigation on the pre-arranged marriage projects between British families. The specialist in British household affairs stated that "In the sixteenth century [...] it has been seen that [...] marriages tended to be arranged by parents rather than by the children themselves" (1977, p.89). More so, the father to Desdemona frequently insisted on this aspect of things. Being an influent member of Venetian aristocracy, Senator Brabantio expected an arranged marriage with an aristocratic family of Venice, and not with someone socially below him. "My daughter" the Senator used to speak to young people threateningly saying "I've charged thee not to haunt about my doors/ [she] is not for thee" (OTH, 1.1.24). Senator Brabantio meant that his daughter Desdemona should get married to someone from the 
Venetian aristocracy. This ambitious project disqualified and naturally excluded a lot of people including Othello from the potential suitors to Desdemona. Philip C. Kolin was in agreement with Shakespearean Brabantio to think that any attempt to twist this pre-established principle may equate with the act of "robbing Desdemona of her personhood" (2002, p.22) of being a true Venetian lady. Kolin and Brabantio were persuaded that by getting married to a man who is socially inferior to her, precisely "a black man" which was synonymous to degeneracy and damnation (Vaughan et al., 1991), Desdemona endangered her social status along with the privilege bestowed on that social rank. Patricia Parker took prompt actions caricaturing the new physical appearance of Brabantio's Desdemona. In her rendition, the critic mentioned that in the marriage relationship with the black Othello, "Desdemona the white Venetian daughter becomes, as it proceeds, the sexually tainted woman traditionally condemned as "black,""' (1994, p.95).

Getting married to someone of the same social rank, was central to the enterprises Brabantio planned previously to convince his daughter. The Senator attempted to make his daughter understand that her Othello was not only a non-Venetian but her union with the alien and particularly the way the wedding was celebrated did not conform to Venetian habits. Stone reacted to Brabantio's anxiety providing it with leading insights. The scholar explained that "[...] the marriage performed at night $[\ldots]$ in private houses $[\ldots]$ was declared illegal" (1977, p.32). Therefore, Brabantio and Stone agreed to say that the union between Othello and his daughter was null and void. According to Brabantio and Stone's line of thoughts, Othello and Desdemona were not husband and wife. The denial of any legitimacy to this union led to the immediate summoning of the Moor to the Senate of Venice.

Observing Venetians' conditions to marriage occurred as the fundamental path which sanctioned the final step of the union between a man and woman. Thus, knowing these conditions was of capital importance to Brabantio. In his explanation, the father to Desdemona underscored that marriage in Venice was meant to bond families and relatives. Therefore, the wedding ceremony could not take place unless the parents were involved in the whole process. This official trait of marriage according to Brabantio confirmed its public characteristics in Shakespearean Venice. Marriage in Venice did not associate only a couple of persons, as Othello and Desdemona pretended to make it seem in the play. Rather, it is supposed to unite and assemble the family and relatives of the concerned people. So to speak, the family of Othello and relatives of Brabantio were expected at the wedding ceremony of their daughter and son. This teaching insight was the one the father to Desdemona wanted his daughter to keep in mind. The Senator did not doubt that the perfect knowledge of the way Venetians organized and celebrated marriage would help Desdemona keep the foot firmly rooted in 
home culture. According to Mike Storry and Peter Childs, Brabantio was convinced that when Desdemona mastered her cultural ways she would discover "a reflection of herself in the mirror of [Veniceness]" (2002, p.285). A way to comprehend and interpret the assertion of the scholars was that Desdemona may confirm her Venetian aspect if only she could comply with Venetians' cultural recommendations. Due to this argumentation, the underlying ideas of Brabantio's ambitious project reinforced the argument that when someone knew the way his/ her traditional events operated or were implemented, this person could easily and naturally avoid some misbehaving acts, such as the one Desdemona perpetrated.

Contrary to what Desdemona and her black Moor thought and accessed as an "emergence of better feelings [...] in Desdemona" (Bradley, 1937, p.204-303), when the Venetian lady succeeded in radically upsetting Venetians' wedding tradition, it was indisputable that her attitude rather exhibited her profound ignorance and record contempt for the principles and rules that ran celebrations in her society. The Othello, singularly "Mrs. Othello", failed to involve and empower her parents to carry out their duty of choosing a husband for her. Ironically, Desdemona succeeded in celebrating her union in such "an extremely unusual and strange" (Bradley, 1937, p.71) way secretly at night when Venetians were asleep. The union of Othello and Desdemona was rife with imperfection. The adumbration of imperfection that caused decay was at the forefront of Susan Frye examination of the union of Othello and Desdemona. In her exploration of the context and condition prior to their wedding, the critic further concluded that the marriage was "spot of adulterous lust" (2010, p.226).

The arguments underlying the previous insights, which Brabantio viewed as an optimal step to enforce some customary teachings, was that the occasion of a celebration could help correct and adjust errors that may be observed in people enactment especially before, while, and after the event had taken place. The father to Desdemona revealed that if he was firmly opposed to Othello's wedding with Desdemona, it was because he noticed a number of poor and outraging facts in the whole process which he ambitioned to rectify. Upon the nighty event that finalised their atypical wedding, Senator Brabantio exhibited the deviant attitudes of his daughter Desdemona. An aspect of the disturbing attitude of Desdemona implied her rebellion against the dictum that Venetian's daughters "may not forget the duties [...] they should not marry without the consent and direction of their parents" (Cleaver, 1598, p.352-53). Also, to Brabantio, the deviancy of his daughter, Desdemona, exposed and laid open his social respectability and honour to ridicule and mockery. Some Venetians gentlemen did not mind coming nightly to his house and "Mock him, poison his delight/ Proclaim him in streets by calling [him] aloud" (OTH, 1.1.22). This harmful situation invaded the mind of the Senator. Actually, the 
shameful-degrading image of his personality took possession of the memory of Brabantio in such a way that he could remember accurately the shameful scenes of his daughter Desdemona.

The father to Desdemona noticed that his daughter used to pay a nightly friendship visit to her would-be husband and came back home early in the morning. Some people gossiped that Venetian people used to see Othello and Desdemona at night standing and kissing lovingly in the streets of Venice. However, Brabantio made the Venetian people believe that, in the Venetian tradition, a fiancée should not wander late at night with her fiancé. In addition, Senator Brabantio persuaded his daughter that the lady who projected to get married in the coming days secretly lived her relationship with her mate until their union was publicly officialised. The exploration of the living conditions of the early modern England lady by Frye and Karen Robert, entailed the comprehension that an Elizabethan lady was expected to have a private life and obedience to the traditional restrictions placed on her social relations and people involved in that relationship (1999, p.9-216). The precious precautions, which Brabantio and the scholars brought up, represented recommended attitudes a Venetian bride and groom should observe to avoid people gossiping.

The previously advised words that aimed to clean up the relationship of Desdemona operated as tremendous indication and instructions not specifically for the lady. The underpinned suggestions were directed at Venetian ladies with the main objective to awaken the careful mind of Venetian fathers who, Shakespearean Brabantio thought, must not blindly trust their daughters because of the deceiving attitudes they craftily hid. Brabantio alerted "Fathers, from hence, trust not your daughters' minds/ by what you see them act" $(O T H, 1.1 .30)$. One way to access the Senator's desperate calling was that the father to Desdemona requested Venetians fathers to permanently keep an open eye on the actions and enterprises of their daughters. Being precious and priceless to the community, Brabantio's reflexion provided a clearer understanding of how the upbringing of one's daughter, according to Venetians' ways, could result to an indisputable legacy for the future generation.

\section{Cultural Identity in Perspective: Legacy to the Future Generation}

One way to teach, raise, enhance, and ascertain the continuity of one's cultural identity is to transfer it to the next generation. This is seen as enculturation. This process equates to a large extent with strategies that aim at the growth of one's cultural identity, and this helps keep its use seamlessly by the coming generations. The process of enculturation implies a number of stages which purposefully shields the exact traits and characteristics of one's cultural identity from corruption and alteration. In this perspective, handing 
over one's cultural identity absolutely includes the group of people that constitutes the close future generation. Since culture is linked with the very fate of the coming generation, Shakespeare's Brabantio was indisputably persuaded that his daughter Desdemona was the "true standard" for running, maintaining, and perpetuating Venetian cultural identity the way she inherited it from her father. The Senator undertook to bequeath the tenets of Venetian cultural identity to Desdemona because Brabantio thought that the lady was on the borders of a dialectic world: daughterhood and womanhood. In fact, Brabantio's daughter, Desdemona, was about to leave the single woman status and embark on housewife life.

In $O T H$, Desdemona represented the future generation. Therefore, her father was convinced that the lady was quite trustworthy to practice, apply, and preserve the Venetian cultural identity as she received it from him. Shakespearean Brabantio confirmed that he brought up his daughter according to Venetian ways. The Senator attested that his daughter Desdemona used to live with him, and he permanently kept a close eye on her actions. Brabantio also stated that his daughter Desdemona did know that she should not go out without the consent of her father. Officially being a single woman, Brabantio used to warn his daughter Desdemona about having or undertaking a love relationship with someone outside the marital link. This motive was central to his threatening words towards Iago and Roderigo at the opening lines of (1.1). Actually, Desdemona upheld everything Venetian culturally valued. Thus, being on the verge of housewife status, she stood as the indicated individual who could promote Venetian cultural ways as her father always wished.

Upon the occasion of the Senate's summon, the daughter to Brabantio showed all the qualities (in terms of education) her father proudly said about her. More so, on the question of parents and housewife duties, the lady pointed out that both her father and husband deserved a separate type of respect and obedience. Desdemona artfully presented those female responsibilities into two "divided duty". Being the daughter of Brabantio, Desdemona explained firstly that "[she] is bound for life and education [...] to [him]". On the other hand, she confessed "the Moor is her husband" $(O T H, 1.3 .54)$ and she owed him the requested submission. Arguing that she was the daughter to Senator Brabantio and now wife to General Othello, the insight of lady Desdemona put in relief an old cultural tradition that the Elizabethans observed piously long ago. A number of experts at Shakespearean Elizabethan social norms, including Bruce. W. Young (2009) and Doran and Jones (2014) revealed that the mentioned "divided duty" may refer to the different cultural behavioural attitude a daughter and a wife must pay attention to, when she addressed her father or interacted with her husband. According to these experts, obeying a father was much different from responding and implementing submissively to one's domestic services. "A father", Lenker further explained, must be 
obeyed - because he is "the very foundation of [...] the family" (Lenker, 2001, p.49).

Prior to the preceding argumentation, there were good reasons to assert that in Elizabethan British society, parental duty was ranked differently from marital and domestic services. A father held the figure of natural authority, and a daughter is naturally dutiful to him. Young explained further that the father heads the family, and he is legally responsible for the family [members] (Young, 2009, p.24). Furthermore, Shakespearean Elizabethans considered that a wife was engaged and is subdued to her husband according to a given cultural prescription and supervised by conventional standards. According to these people, the wife ought to respect and carry out her household tasks with regard to the social directives that drive any relationship based on marriage contract. Therefore, one could assume that the notion of "the divided duty" raised two different types of obedience, namely obedience by habit or custom and obedience stated by social norms and the law. Also, distinguishing between father's and husband's authority confirmed the good educative features Brabantio's Desdemona was famous with. Similarly, Desdemona know-how in household tasks could be analysed as being the trigger for the amount of respect and consideration which her husband Othello devoted to her. This situation gained on weight especially when Othello treated and assessed his wife Desdemona as the best of wives. Desdemona provided her husband with comforting assistance in situations which most wives would abandon their partner.

Following the day of her honeymoon with Othello in (1.3), Desdemona expressed a stoic constancy to assist her husband on the battlefield amidst the danger of war. While she stayed at home passively waiting obliviously for her husband, the daughter to Brabantio behaved respectfully and got the permission from the Duke to go with her Othello to combat the Turk. On another occasion, the exceptional household qualities of Desdemona as the stereotype of a Venetian wife illustrated itself in an expressive way. Her exceptionally kind treatment of Othello fascinated Venetian, and Emilia was the most fascinated. The lady used to wonder "What should such a fool/ do with so good a wife?" (5.2). "It was for love," Desdemona simply replied. In the course of the play story, the loyalty of Desdemona household expressed itself by her loving carefulness with the social image of her husband. In fact, when Othello was racially abused by some detractors headed by Iago, Roderigo and others, the Moor was psychologically comforted by his wife. Desdemona challenged the thrilling depth of the night obscurity to highlight the heroic strengths and qualities of Othello and underpin with force the marital dimension of the man she loved. To the audience, Desdemona indisputably convinced the Duke that Othello "is indicted falsely" (3.4), yet, 
the Moor her husband, was quite a loving man and she "did love him to live with him" (1.3).

The protecting image process Desdemona got involved in was part of the diplomatic household responsibility Shakespearean Elizabethan ought to implement tactfully to keep her family name and the social image of her husband. Although presumably known as silent and patriarchally voiceless, Elizabethan women were supposed to speak up their mind artfully and craftily in situations that may negatively influence the family's societal image through the permanent attack on the respectability of its head. This remark was true and especially indisputable for aristocratic class women, and Desdemona was a leading figure. Many scholars were of the view that culturally speaking, the archetype of an Elizabethan household was that a woman or wife should be famous for, and socially well-known for her artful management of domestic services as well as the family private situations. D. Kemp depicted such an ideal woman in terms of an "obedient, chaste, modest and [...] patient wife" (Kemp, 2010, p.2). Furthermore, Brabantio's Desdemona was believed to be endowed with the mentioned qualities.

Brabantio reassured the Senate that he equipped his daughter with the cultural elements necessary for managing a father, handling carefully her household tasks, and carrying out artfully her domestic services. In doing so, the Senator did not deceive his audience, especially when he chose and built his expectations on Desdemona as the ideal lady to perpetuate Venetian tradition in which its cultural identity was the most prevailing element. In addition, Desdemona's constant employing of her Venetian traditional practices were hints to ascertain the audience that the daughter to Brabantio was assuredly up to promote Venetian cultural identity. With regard to the commitment of Desdemona in Venetian tradition, the audience believed that she was in perfect harmony with the view of her father. More so, the achievement of this outstanding cultural project justified his complaints from the opening scenes to the closing acts of the play.

\section{Conclusion}

The rise of a British cultural identity spoke to the Elizabethan audience as the idealistic forum Shakespeare thought of to forge the necessary idea related to the promotion, defence, and perpetuation of a cultural identity which is proper to the country. His many attempts to make Othello understand the necessity to behave as a Venetian culminated in frustration on the part of the Moor. The occasional husband to Desdemona expressed his stern attachment to his ways, which in the mind of Shakespeare was detrimental to the community his wife originated from. Like any Venetian engaged in this process, Shakespeare could hardly accept the offense that the ridiculing attitude of the Moor caused to senator Brabantio and by extension to 
Venetians. The refusal of Othello to marry Desdemona according to Venetian practices, or following the path her father described, constituted the slightest crux of problems that opposed Othello to Shakespeare and to the whole Venetian community. Shakespeare observed that Othello seemed naturally unable to obey Venetian ways. Thus, based on the explanations of Brabantio, the playwright was self-assured that Desdemona would never get marry outside the cultural tenets of Venetian tradition.

Faced with what many scholars considered as a social injustice to Desdemona rather than to Othello, Shakespeare found and seized the opportunity to impose the Venetian ways on aliens including the Moor. In this perspective, Shakespeare summoned Othello to appear in Venetian Court for his atypical treatment of the marriage affair between him and Desdemona. Also, behind the questioning of the Moor, Shakespeare invested in recommendations that the accused should care about, if he planned or felt like living beyond reproach in the Venetian community. Through the opposition of Othello to Venetian traditional ways, Shakespeare aimed to reinforce a quest. This was the quest for a national identity that may confirm the originality along with the particularity of the identity of Venetian within the globalized trends which individual identities are still submitted to.

\section{References:}

1. Azmil Zabidi, M. (1990): Othello and the quest 1 on of race: a review of two decades of criticism, Iowa: State University.

2. Bradley, A.C. (1937). Shakespearean Tragedy. London: Macmillan and Co, Limited.

3. Cleaver, R. (1598). A Godly Form of Household Government. London: Felix Kingstone.

4. Cros, E. (1988). Theory and Practice of Sociocriticism. USA: Library of Congress Cataloguing-in Publication.

5. Doran, S. \& Jones, N. (2014). The Elizabethan World. London and New York Routledge.

6. Drakakis, J. (2008). "Shakespeare and Venice". In Italian Culture in the Drama of Shakespeare and his Contemporaries: Rewriting, Remaking, Refashioning. Ashgate: Michele Marrapodi, Aldershot.

7. Durband, A. (2006). Shakespeare: Othello. United Kingdom: Nelson Thornes Ltd.

8. Frye, S. \& Robert, K. (1999). Maids and Mistresses, Cousins and Queens: Women's Alliances in Early Modern England. New York: Oxford University Press.

9. Frye, S. (2010). Pens and Needles: Women's Textualities in Early Modern England. USA: University of Pennsylvania Press. 
10. Kemp, D Theresa (2010). Women in the Age of Shakespeare. England: Greenwood Press.

11. Kolin, PC. (2002). Othello: New Critical Essays. London: Routledge.

12. Lenker, TL. (2001). Fathers and Daughters in Shakespeare and Shaw. London: Greenwood Press.

13. Michelle Dowd \& Natasha Korda (2011). Working Subjects in Early Modern England Drama. USA: Ashgate Publishing Limited.

14. Orkin Martin (1987). "Othello and the Plain Face of Racism". Shakespeare Quarterly 38, pp.166-88.

15. Parker Patricia (1994). Fantasies of "Race" and "Gender". London: Routledge.

16. Richard, Taylor, \& John Edward (1838). The British and Foreign Review, or European Quarterly Journal. London: Red Lion Court, Fleet Street.

17. Singnam Jeffrey, L. (1995). Daily Life in Elizabethan England. London: Greenwood Press.

18. Stone Laurence (1977). The Family, the Sex and Marriage in England 1500-1800, London: Harpero Row Publisher.

19. Storry Mike \& Peter Childs (2002). British Cultural Identities. London: Routledge.

20. Vaughan, Virginia, Mason, Kent, \& Cartwright (1991). Othello: New Perspectives. Michigan: Fairleigh Dickinson University Press.

21. Young, WB. (2009). Family in the Age of Shakespeare. London: Greenwood Press. 